\title{
KHURUJ DAN KEHARMONISAN KELUARGA JAMAAH TABLIGH DI KABUPATEN BONE
}

\author{
Oleh. SAMSIDAR \\ Fak. Syariah dan Hukum Islam, IAIN Bone, Indonesia \\ samsidarfahri@gmail.com
}

\section{Article history:}

Received: $10-01-2020$

Revised: $27-03-2020$

Accepted: $12-04-2020$

\begin{abstract}
This study aims to determine the attitude of the Tablighh Jamaat when leaving the family (Khuruj) on the rights and obligations in the household in building harmony in the Tablighi Jamaah family in Bone Regency. This research is important. that the life of the followers of Tablighh is rife with followers and that not a few families who join the tabligh congregation cause ripples of family disharmony in Bone district. Field research methods using the sociological approach and normative theological approach.

The results in the field found that. There are three attitudes of the people of Bone Regency. First, families do not accept and are not willing to be left out (Khuruj) had to be left by the head of his family or her husband who in fact this family ended in divorce. While the second, the family did not fully accept, when leaving a ripple arose disputes within his family, as well as when the head of his family returned home to accept but was forced to live in ambiguous two choices to survive by always causing disputes in the family. While the three, families fully accept, this is solely a world affairs, are no longer important but world life is a temporary stopover, all because of lillahitaala.
\end{abstract}

\section{Keywords: Harmony; Jamaah Tabligh; Khuruj.}

\begin{abstract}
Abstrak
Penelitian ini bertujuan untuk mengetahui sikap Jamaah Tabligh ketika meninggalkan keluarga (Khuruj) akan hak dan kewajiban dalam rumah tangga di dalam membangun keharmonisan keluarga Jamaah Tabligh di Kabupaten Bone. Penelitian ini penting karena kehidupan Jamaah Tablighh marak pengikutnya dan tidak sedikit keluarga yang bergabung dalam Jamaah Tabligh menimbulkan riak disharmonisasi keluarga di kabupaten Bone. Metode penelitian field research dengan menggunakan pendekatan sosiologis dan pendekatan teologis normatif.

Hasil di lapangan ditemukan bahwa, terdapat tiga sikap masyarakat Kabupaten Bone. Pertama, keluarga tidak bisa terima dan tidak rela jika harus ditinggal Khuruj oleh kepala keluarganya ataupun suaminya yang pada kenyataannya keluarga ini berakhir dengan perceraian. Sedangkan yang kedua, keluarga tidak menerima sepenuhnya, ketika ditinggal timbul riak perselisihan dalam keluarganya, begitupun saat kembali kepala keluarganya ke rumah menerima namun terpaksa hidup dalam ambigu dua pilihan, bertahan dengan
\end{abstract}


selalu menimbulkan percekcokan dalam keluarga. Sementara Ketiga, keluarga menerima sepenuhnya, hal ini semata-mata urusan dunia, bukan lagi hal penting akan tetapi kehidupan dunia adalah persinggahan sementara, semua karena lillahitaala.

\section{Keywords: Jamaah Tabligh; Keharmonisan; Khuruj.}

\section{A. Pendahuluan}

Jamaah Tabligh merupakan sebuah gerakan keagamaan yang mempunyai konsep gerakan dengan cara dakwah dan tabligh. Adapun metode dari Jamaah Tabligh dalam melaksanakan dakwah sering dikenal istilah Khuruj, yakni keluar dari rumah ke rumah, dari kampung satu ke kampung yang lain dan bahkan ke luar negeri. Konsep Khuruj dalam aplikasinya terdiri dari tiga tahap, yakni 3 hari dalam sebulan, 40 hari dalam setahun, dan 4 bulan sekali dalam seumur hidup.

Berkaitan dengan pernyataan di atas, penulis ingin mengetahui keharmonisan keluarga Jamaah Tabligh ketika ditinggal Khuruj oleh kepala keluarganya, lalu bagaimana dengan kewajibannya terhadap keluarga yang ditinggalkan. Karena di sisi lain, ia juga harus menjalankan kewajiban sebagai kepala keluarga sebagaimana mestinya, antara lain memberikan nafkah lahir dan batin, menjamin keamanan dan pertahanan dan lain sebagainya.

Dengan begitu, tujuan dari penelitian ini yaitu untuk mengetahui apakah keluarga Jamaah Tabligh memiliki konsep keharmonisan keluarga tersendiri dalam membangun keluarganya. Jadi, penelitian ini berusaha untuk memberikan penafsiran terhadap gejala-gejala yang ditemui di lapangan, tentunya sesuai dengan fokus penelitian yang telah ditentukan dan juga menggunakan teori yang relevan tentang keluarga, untuk bisa mengungkap keharmonisan keluarga Jamaah Tabligh dalam membangun kehidupan keluarga.

Di kalangan masyarakat Islam, banyak metode dakwah yang dilakukan oleh para Da'i, salah satunya adalah dakwah yang dilakukan oleh kalangan yang dilakukan yang bernama Jamaah Tabligh. Hal yang sangat menarik dari metode dakwah yang dilakukan oleh para anggota Jamaah Tabligh yang mayoritas anggotanya adalah kepala rumah tangga, ialah apabila sedang melakukan dakwah atau yang biasa disebut dengan tabligh, mereka mempunyai metode yang sering mereka sebut Khuruj fi sabilillah. Khuruj adalah meluangkan waktu untuk secara 
total berdakwah, yang biasanya dari masjid ke masjid dan dipimpin oleh seorang amir.

Dalam melakukan hal tersebut para anggota Jamaah Tabligh keluar meninggalkan keluarganya untuk melakukan tabligh dengan mengandalkan biaya sendiri dan meluangkan waktunya ke berbagai penjuru Desa, kota bahkan mancanegara dalam jangka waktu tertentu antara 3-40 hari, 4-7 bulan bahkan satu tahun.

Manusia diciptakan sebagai mahluk sosial yang tidak bisa hidup sendiri, tanpa orang lain dalam mengarungi bahtera kehidupannya, Ketika kedua belah pihak telah terikat maka sejak itulah mereka mempunyai kewajiban selaku suamiistri dalam keluarga yang tidak mereka miliki sebelumnya. Apabila akad nikah telah berlangsung dan sah, serta memenuhi syarat dan rukunnya maka akan menimbulkan akibat hukum, sedangkan yang dimaksud dengan kewajiban adalah apa yang mesti dilakukan seseorang terhadap orang lain.

Berbicara mengenai Kewajiban suami dan kewajiban istri, maka suami adalah pembimbing terhadap istri dan rumah tangganya, akan tetapi mengenai halhal urusan rumah tangga yang penting-penting diputuskan oleh suami-istri bersama. ${ }^{1}$ Adanya kewajiban suami dan istri dalam kehidupan rumah tangga juga dapat dilihat dalam QS al-Baqarah/2: 228.

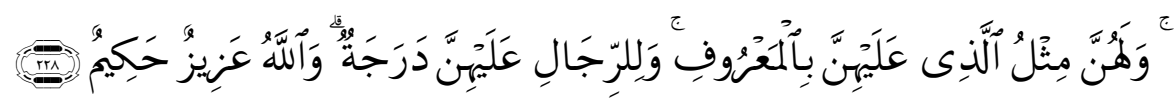

Terjemahannya:“...dan para wanita mempunyai hak yang seimbang dengan kewajibannya menurut cara yang ma'ruf, akan tetapi para suami, mempunyai satu tingkatan kelebihan daripada istrinya. dan Allah Swt. Maha Perkasa lagi Maha Bijaksana".2

Maksud dari makna ayat tersebut adalah hak yang dimiliki oleh seorang istri seimbang dengan kewajiban istri tersebut terhadap suaminya. Karena hak yang diterima satu pihak adalah merupakan kewajiban bagi pihak yang lain. Nafkah adalah hak seorang istri, dan sebaliknya pemberian hak ini kewajiban

\footnotetext{
${ }^{1}$ Amir Syarifuddin, Hukum Perkawinan Islam Di Indonesia (Cet I; Jakarta: Pranada Media, 2006), h. 60.

${ }^{2}$ Departemen Agama RI Al-Qur'an dan Terjemah (Semarang: CV Alwaah, 1989), h. 36.
} 
suami terhadap istri. Selain nafkah materil, seorang suami juga berkewajiban untuk memberikan nafkah batin terhadap istrinya dalam bentuk interaksi dengan baik.

Suatu hal yang sangat menarik untuk diteliti bagi keluarga Jamaah Tabligh di kabupaten Bone dimana meninggalkan keluarga dengan jangka waktu 3 hari, 40 hari ataupun satu tahun dengan melakukan metode Khuruj ditemukan di lapangan bahwa keluarga yang ditinggal oleh kepala keluarga dalam hal ini suami untuk berdakwah dengan metode Khuruj istri tidak setuju bahkan tidak sedikit berakhir dengan perceraian. Karena ketidakrelaan tersebut, keharmonisan keluarga terganggu dan banyak hal yang harus diterapkan, seperti sikap saling menyayangi, saling pengertian dan saling menghormati, saling melaksanakan hak dan kewajiban di dalam rumah tangga oleh Jamaah Tabligh di Kabupten Bone.

Berdasarkan pijakan berfikir di atas maka permasalahan dalam penelitian tentang sikap Jamaah Tabligh ketika meninggalkan keluarga (Khuruj) terhadap hak dan kewajiban dalam membagun keharmonisan keluarga Jamaah Tabligh di Kabupaten Bone.

\section{B. Metode Penelitian}

Jenis penelitian ini adalah penelitian lapangan dengan pendekatan kualitatif. Penelitian kualitatif ini merupakan penelitian yang memusatkan perhatian pada prinsip-prinsip umum yang mendasari perwujudan sebuah makna dari gejala-gejala sosial masyarakat. Dengan metode kualitatif, data disajikan secara langsung di lapangan dan hakikat hubungan antara penelitian dan responden serta metode kualitatif lebih peka dan lebih dapat menyesuaikan diri dengan banyak penajaman pengaruh bersama terhadap pola-pola nilai yang dihadapi.

Data diperoleh dari hasil wawancara dengan tokoh agama dan keluarga Jamaah Tabligh di Kabupaten Bone. Narasumber atau informan yang dianggap berpotensi memberikan keterangan yang valid, dipilih sebagai key-informan dalam pengambilan data di lapanganan. Mengenai hal ini yang menjadi informan adalah Jamaah Tabligh sebagai kepala keluarga yang Khuruj. 
Informan lain, yaitu para istri jamaah tabligh sebagai triangulasi data. Bagaimana pengalaman mereka dalam mewujudkan keutuhan keluarga dalam kehidupan keluarga Jamaah Tabligh Pendekatan sosiologi sebagai ilmu yang mempelajari hidup bersama dalam masyarakat dan menyelidiki ikatan antara manusia serta nilai-nilai yang menguasai hidupnya itu. Dengan ilmu ini suatu fenomena sosial dapat dianalisis dengan faktor-faktor yang mendorong terjadinya hubungan, mobilitas sosial serta keyakinan-keyakinan yang mendasari terjadinya proses tersebut. Selanjutnya sosiologi dapat digunakan sebagai salah satu pendekatan dalam memahami agama. ${ }^{3}$

Dalam rangka pengumpulan data-data yang diperlukan dalam pembahasan penelitian ini, maka peneliti menggunakan beberapa metode sebagai berikut observasi, wawancara, dan dokumentasi. Untuk analisis data kualitatif ini maka perlu ditekankan beberapa tahapan dan langkah-langkah sebagai berikut : reduksi data, display data, serta penarikan kesimpulan atau verifikasi. ${ }^{4}$

\section{Kajian Teori}

\section{Khuruj}

Secara ringkas, Khuruj dalam Jamaah Tabligh adalah keluarnya seseorang dari lingkungannya untuk memperbaiki diri dengan belajar meluangkan sebagian harta serta waktunya dari kesibukan perkerjaan, keluarga dan urusan-urusan yang lain, demi meningkatkan iman dan amal shalih semata-mata karena Allah Swt. ${ }^{5}$

Agama adalah anugerah terbesar sekaligus sumber keridhaan Allah Swt. Menunaikan Agama secara sempurna adalah satu-satunya cara untuk mendapatkan ridha Allah Swt. Karena demikian pentingnya agama bagi manusia, Allah Swt. telah mengutus para Anbiya as. Untuk mendidik manusia agar menerapkan agama secara sempurna sebagai pedoman hidupnya, dan perjuangan

${ }^{3}$ Abuddin Nata, Metodologi Studi Islam (Cet. IV; Yogyakarta: Gajah Mada University Press, 2012) h.28.

${ }^{4}$ Harun Rasyid, Metodologi Penelitian Kualitatif Bidang Ilmu Sosial dan Agama (Pontianak: IAIN Pontianak, 2008), h. 71

${ }^{5}$ Abdurrahman Ahmad As-Sribuny, Kupas Tuntas Jama'ah Tabligh, (Cerebon: Pustaka Nabawi, 2012,), h. 147. 
serta pengorbanan seorang beriman demi agamanya, adalah bukti keimanan dan kecintaan kepada Allah Swt. dan Rasul-Nya. ${ }^{6}$

Sedangkan Khuruj berasal dari bahasa Arab yaitu kharaja yang mempunyai arti keluar. "Keluar" yang dimaksud adalah suatu usaha amal untuk keluar berdakwah guna mengajak manusia beribadah kepada Allah Swt. dan meninggalkan apa yang dilarang-Nya. Selain itu bagi Jamaah Tabligh, Khuruj ini wajib hukumannya bagi setiap manusia (keluar untuk berdakwah). ${ }^{7}$

Khuruj atau keluar untuk berdakwah itu merupakan zakat waktu. Apabila sudah mencapai nishab, maka mereka diwajibkan untuk berdakwah atau dengan kata lain meluangkan waktu mereka untuk kepentingan agama dan berjuang di jalan Allah Swt. Adapun nishab waktu tersebut adalah 1,5 jam untuk satu hari, 3 hari untuk satu bulan, 40 hari untuk satu tahun dan jika memungkinkan 4 bulan untuk seumur hidup. ${ }^{8}$

\section{Tabligh}

Tabligh diartikan menyampaikan ajaran Islam oleh Rasulullah Saw. dan umatnya. Tabligh merupakan kewajiban bagi setiap muslim. Pembawa misi Islam adalah Rasulullah Saw., semua yang disampaikannya bertitik tolak dari wahyu. Jika risalah itu disampaikan oleh umat Nabi Saw., materi dakwahnya menjadi lebih luas. Selain al-Qur'an dan al-Sunnah, menurut mereka sebagian ulama, juga menggunakan ijma' dan qiyas.

Saat ini terjadi fenomena menarik dari gerakan keagamaan Islam, yakni munculnya Jamaah Tabligh yang kian merebak. Salah satu ciri khas gerakan Jamaah Tabligh adalah adanya konsep Khuruj. Khuruj yang berarti "Keluar" dengan maksud bahwa suatu usaha amal untuk keluar berdakwah guna mengajak manusia beribadah kepada Allah Swt. dan meninggalkan apa yang dilarang-Nya.

\footnotetext{
${ }^{6}$ Abdurrahman Ahmad As-Sribuny, Kupas Tuntas,,, h. 148.

${ }^{7}$ An Nadr M. Ishaq, Khuruj Fisabillah : Sarana Tarbiya Ummah Untuk Membentuk sifat Imaniyah, ( Bandung : Al Islah Press, 2012), h.

${ }^{8}$ Husein Muhammad, Fiqh Perempuan: Refleksi Kiai Atas Wacana Agama dan Gender, (Yogyakatrta: LKIS, 2001,), h. 121.
} 
Selain itu Khuruj ini wajib hukumnya bagi setiap manusia keluar untuk berdakwah. $^{9}$

Dalam Konsepsi Jamaah Tabligh, seseorang akan dianggap pengikut Jamaah Tabligh jika sudah turut serta Khuruj. Bagi Jamaah Tabligh merupakan sebuah kewajiban. Konsep Khuruj yang dibangun Jamaah Tabligh ini berdasarkan landasan teologis pimpinan jamaah landasan hukum bagi Jamaah Tabligh berdasar dari ayat al-Qur'an surah Ali Imran:3/ 104.

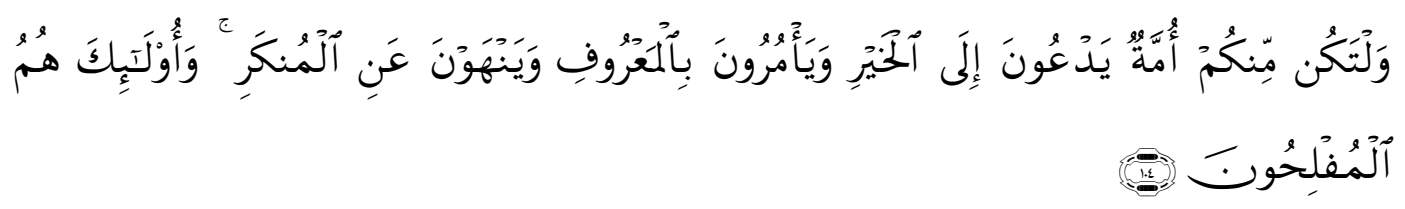

Terjemahnya: "Dan hendaklah ada di antara kamu segolongan umat yang menyeru kepada kebajikan, menyuruh kepada yang ma'ruf dan mencegah dari yang munkar merekalah orang-orang yang beruntung. ${ }^{10}$

Makna penjelasan dalil bahwa ma'ruf diartikan segala perbuatan yang mendekatkan diri kepada Allah Swt.; sedangkan munkar ialah segala perbuatan yang menjauhkan diri dari pada-Nya.

\section{Keluarga Harmonis}

Keluarga adalah lembaga terkecil dalam suatu masyarakat dan dari keluarga seseorang mendapatkan ajaran serta penanaman nilai-nilai serta ajaran agama Islam untuk diamalkan dalam kehidupan bermasyarakat. Dewasa ini setiap manusia menginginkan untuk memiliki keluarga harmonis dan sejahtera.

Dalam agama Islam rumah tangga atau keluarga yang harmonis adalah keluarga sakinah, mawaddah dan warahmah. Hal tersebut bisa dijadikan landasan dalam berkeluarga yang menjunjung nilai-nilai ajaran Islam dalam ketakwaan kepada Allah Swt.

Keluarga secara umum dijelaskan sebagai suatu satuan kekerabatan yang juga merupakan satuan tempat tinggal yang ditandai oleh adanya kerjasama ekonomi, dan mempunyai fungsi untuk melanjutkan keturunan, mensosialisasikan

\footnotetext{
${ }^{9}$ An- Nar M. Ishaq Shahab, Khuruj Fisabilillah;...

${ }^{10}$ Departemen Agama RI Al-Qur'an dan Terjemah (Semarang: CV Alwaah, 1989), h. 78.
} 
atau mendidik anak, dan melindungi, merawat dan menolong anggota keluarga yang lemah seperti bayi, anak-anak atau orang lanjut usia. ${ }^{11}$

Murdock mendefenisikan keluarga sebagai sebuah satuan kelompok yang anggotanya terhubungkan melalui kekerabatan, perkawinan atau adopsi dan hidup bersama-sama, bekerjasama secara ekonomis dan merawat anggota keluarga yang lemah (bayi, anak dan orang lanjut usia). ${ }^{12}$ Hal senada diungkapkan Collins bahwa keluarga merupakan satuan sosial terkecil dari manusia yang mempunyai fungsi penting dalam keberlangsungan hidup manusia. Keluarga tidak saja mencukupi kebutuhan-kebutuhan psikologis manusia seperti kasih sayang, cinta, dan perhatian, tetapi juga kebutuhan-kebutuhan fisik seperti makan, minum atau tempat tinggal. ${ }^{13}$

Kendati demikian, apabila salah seorang suami pergi berdakwah, lalu bagaimana dengan kewajiban mereka untuk membimbing dan mendampingi istri dan anak yang ditinggalkan. Kekhawatiran akan kemungkinan istri melakukan nusyuz bisa saja terjadi, karena sesuatu hal yang mengganggu keharmonisan dalam rumah tangga di antaranya yaitu, hak dan kewajiban antara suami istri yang tidak dilaksanakan secara maksimal. Upaya apa yang dilakukan oleh para suami pengikut Jamaah Tabligh dalam memberikan pengertian terhadap istrinya mengenai kewajiban yang mereka emban yaitu dakwah, yang pelaksanaannya dilakukan dengan meninggalkan istri dan keluarga. Karena tidak semua istri akan benar-benar bisa mengerti dan memahami akan kegiatan yang dilakukan oleh suaminya, apalagi kegiatan dakwah suami tersebut dilakukan dengan cara meninggalkan keluarga istri dan anak dalam jangka waktu yang tertentu.

\section{Pembahasan}

Jamaah Tabligh merupakan gerakan transnasional dakwah Islam, yang bergerak mulai dari kalangan bawah, kemudian merangkul seluruh masyarakat muslim tanpa memandang tingkatan sosial dan ekonomi dalam mendekatkan diri

\footnotetext{
${ }^{11}$ Widjaja, Manusia Indonesia: Individu, Keluarga dan Masyarakat, (Jakarta: Akademika Pressindo, 1986), h. 21

${ }^{12}$ Murdock, The Sosial Experience:Introduction to Sociology, (USA: Random House, 1999), h. 33

${ }^{13}$ Collins, Sociololgy of Marriageand The Family:Gender Love and Property, (USA: Nelson Hall inc 1996), h.32
} 
kepada ajaran Islam. Jamaah Tabligh didirikan pada akhir dekade 1920-an oleh Maulana Muhammad Ilyas Kandhalawi di Mewat, dia lahir pada tahun 1886 di desa Kandahlah India. sebuah provinsi di India.

Tabligh resminya bukan kelompok atau ikatan, tapi gerakan muslim untuk menjadikan muslim yang menjalankan agamanya, dan hanya satu-satunya gerakan Islam yang tidak mamandang asal-usul mazhab atau aliran pengikutnya. Jamaah ini juga mempunyai amalan-amalan khusus dan juga agenda dakwah yang telah disusun dalam musyawarah. Kegiatan dakwah tersebut tidak berlangsung sebentar, serta sifat dari pada kegiatan ini adalah Lillahitaala, artinya kegiatan ini dilakukan tanpa ada imbalan apapun kecuali pahala dari Allah Swt. Karena dakwah bukanlah profesi akan tetapi merupakan suatu kewajiban. Seseorang yang telah menjadi anggota dari pada gerakan ini, tentu harus selalu mengikuti kegiatan-kegiatan termasuk dakwah Islam yakni landasannya dakwah dengan Khuruj di jalan Allah Swt. ${ }^{14}$

Kemudian bagaimana sikap Jamaah Tabligh ketika meninggalkan keluarga (Khuruj) akan hak dan kewajiban keluarga (Suami - Istri) di Kabupate Bone? tentu suami dan istri memiliki hak dan kewajiban dalam berumah tangga. Seorang suami harus memenuhi haknya kepada istrinya dengan baik seperti, nafkah, membahagiakan istri dan mewujudkan kehidupan yang tenang dan damai sebagaimana yang diinginkan. Suami juga harus membimbing istrinya dengan baik dan sabar dalam kebaikan dan ibadah. Hak dan kewajiban suami terhadap istri dalam metode dakwah yang dilakukan oleh Jamaah Tabligh pada dasarnya apabila yang dilakukan oleh mereka sesuai dengan prosedur yang menjadi syarat untuk melakukan Khuruj maka tidak terdapat kesalahan terhadap hak dan kewajiban suami terhadap istri dan anak-anaknya. Hal ini sesuai dengan apa yang disampaikan oleh Bapak A. Fadli Bahtiar, beliau mengatakan bahwa:

"Kewajiban seorang suami dalam berumah tangga adalah memberikan nafkah kepada istrinya serta mendidik dan menjaga segala kehormatan istrinya. Kewajiban suami adalah sesuatu yang harus dilakukan oleh suami sebagai kepala rumah tangga terhadap istri dan anggota keluarga

${ }^{14}$ Haidlor Ali Ahmad, Respon Pemerintah Ormas dan Masyarakat Terhadap Aliran Keagamaan di Indonesia, (Jakarta: 2007), h. 17-18. 
lainnya. Oleh karena itu, supaya tercipta rumah tangga yang harmonis dalam sebuah keluarga maka harus selalu menjaga keseimbangan di berbagai segi kehidupannya di antara suami istri. Keseimbangan tersebut bisa diawali dari suami istri sendiri yaitu selalu menjaga keseimbangan hak dan kewajiban di antara mereka. Sebagai seorang suami, menghormati dan mematuhi kewajibannya kepada istri dalam hal memberikan nafkah maka itu merupakan suatu kebahagiaan tersendiri di dalam kehidupan berumah tangga antara suami istri.",15

Hal serupa yang disampaikan oleh Bapak Muh. Ikbal, menurutnya :

"Hak dan kewajiban seorang suami istri dalam berumah tangga harus berimbang, tetapi kewajiban dari seorang suami kepada istrinya itu, selalu memberikan nafkah, memberikan pendidikan agama, melindungi serta memberikan perlakuan yang baik kepada anggota keluarganya". ${ }^{16}$

Mengenai hak dan kewajiban suami istri maka pasti tidak terlepas yang namanya dengan nafkah baik itu dari segi nafkah lahir maupun dengan nafkah batin. Di kalangan Jamaah Tabligh terhadap pemenuhan nafkah keluarga sudah dipenuhi, karena sebelum mereka melakukan dakwah biasanya sudah mempersiapkan terlebih dahulu uang atau nafkah bagi istrinya dengan berbagai macam usaha yang dilakukan seperti berdagang, bekerja, dan lain sebagainya. Hal ini disampakan oleh Bapak A. Subhan, beliau mengatakan:

"Nafkah pada umumnya merupakan tanggung jawab suami untuk mencukupi keluarganya. Meskipun di sini istri bersedia untuk ikut membantu, tetapi itu akan tidak mengurangi kewajiban suami. Karena pada umumnya bahwa suamilah yang lebih berkewajiban untuk memberikan nafkah untuk istri dan anak-anaknya". ${ }^{17}$

Namun pada dasarnya bahwa di kalangan Jamaah Tabligh bahwa ketika sebelum mereka ingin keluar berdakwah dijalan Allah Swt. maka suami tersebut harus meminta izin terlebih dahulu kepada istri dan anggota keluarga lainnya, kemudian memberitahukan kepada anggota keluarganya bahwa mereka akan keluar berdakwah beberapa hari. Adapun waktu yang biasanya Jamaah Tabligh

\footnotetext{
${ }^{15}$ A.Fadli, Wawancara di Mesjid Al-Fatihah Kelurahan Manurungnge Kecamatan Tanete Riattang Kabupaten Bone, 12 Juni 2019

${ }^{16}$ Muh. Ikbal, Wawancara di Kelurahan Manurunge Kecamatan Tanete Riattang Kab. Bone, 14 Juni 2019.

${ }^{17}$ Andi. Subhan, Wawancara di Kecamatan Tanete Riattang Kabupaten Bone, 20 Juni 2019 .
} 
keluar berdakwah yaitu selama 3 hari dalam 1 bulan, 40 hari dalam 1 tahun dan 4 bulan dalam seumur hidup.

Setelah istri mengizinkan suaminya untuk keluar berdakwah maka diadakan musyawarah antara suami dan istri kepada suaminya dengan alasan selama itu tujuannya baik untuk menambah keimanan dan dilakukan untuk menjalankan usaha dakwah dijalan Allah Swt. maka suami istri menghitung besaran nafkah yang akan dibutuhkan istri dan anaknya selama suami melakukan dakwah selama beberapa hari. Hal yang disampaikan oleh Bapak Muh. Ikbal, yaitu:

"Sebelum seorang Jamaah Tabligh pergi berdakwah, diadakan terlebih dahulu musyawarah keluarga yaitu antara suami dengan istri. Seorang suami akan memberitahukan kepada istrinya bahwa ia akan melakukan program dakwah selama beberapa hari. Setelah dimusyawarakan, selanjutnya suami dan istri akan menghitung terhadap besarnya biaya keperluan hidup selama istri dan anaknya ditinggal dalam kehidupan berumah tangga". ${ }^{18}$

Ini juga diungkapkan oleh Bapak Mastam, beliau mengatakan :

"Sebelum berdakwah ada beberapa syarat serta hal-hal yang harus diperhatikan baik untuk diri sendiri maupun untuk anggota keluarga yang akan ditinggalkan selama beberapa hari. Para Jamaah Tablig meminta izin pada istri dan anaknya sebelum pergi berdakwah dan biasanya mereka akan memperkirakan besaran nafkah yang akan mereka berikan kepada keluarganya selama mereka pergi". ${ }^{19}$

Selain hak dan kewajiban suami terhadap istrinya dalam lingkungan Jamaah Tabligh, istri juga memiliki hak dan kewajiban terhadap suaminya. Salah satunya kewajiban seorang istri dalam kehidupan berumah tangga adalah taat kepada suaminya. Istri diwajibkan selalu taat kepada suaminya kecuali dalam halhal yang melarang aturan agama atau kesusilaan. Hal ini diungkapkan oleh Ibu Mirnawati :

"Hak seorang istri dalam kehidupan berumah tangga adalah mendapatkan nafkah dari suami serta mengatur segala urusan di dalam rumah tangga. Seorang istri terhadap hak dan kewajibannya kepada suami ketika sedang melakukan dakwah, maka istri itu harus bersyukur terhadap

\footnotetext{
${ }^{18}$ Muh. Ikbal, Wawancara di Kelurahan Manurungnge Kecamatan Tanete Riattang Kabupaten Bone, 21 Juni 2019.

${ }^{19}$ Hardiyanto, Wawancara di Kecamatan Tanete Riattang Kabupaten Bone, 23 Juni 2019
} 
nafkah yang diberikan, menghidupkan amalan di rumah, berhemat dengan mempergunakan untuk kepentingan agama, puas dengan nafkah yang ada dan senantiasa selalu mendoakan suami agar selalu dalam keadaan sehat".

Selain memberi nafkah, seorang suami sebagai kepala keluarga berkewajiban untuk membimbing, mendidik anak dan istrinya untuk taat kepada Allah Swt., mengajarkan mereka apa yang menjadi kewajiban yang diperintahkan Allah Swt. dan meninggalkan larangan-Nya. Oleh karena itu seorang suami harus mengajarkan ilmu agama baik kepada anak maupun kepada istrinya. Betapa pentingnya ilmu agama dalam keluarga karena agama adalah sarana untuk mengabdi kepada Allah Swt. dan untuk menjauhkan keluarga dari siksa api neraka di akhirat kelak. Ini juga yang dilakukan dalam lingkungan Jamaah Tablig. Hal ini disampaikan oleh Bapak Syamsir Alam:

"Dalam kehidupan berumah tangga bahwa sebagai Orang tua, harus menjadi madrasah pertama bagi anak-anaknya. Seorang suami harus mendidik istri dan anak-anaknya agar semakin dekat dengan Allah Swt. sesuai dengan apa yang telah mereka dapatkan ketika mereka melakukan Khuruj fii sabillillah". ${ }^{0}$

Bapak Ramadhani juga mengatakan bahwa :

"Menghidupkan amalan sunnah di rumah juga dapat dilakukan dalam rangka mendidik istri dan juga anak-anak. Memberikan pendidikan agama yang baik kepada istri dan anak serta mengamalkan ilmu-ilmu yang telah didapatkan ketika melakukan Khuruj fii sabilillah. Dan menjadikan keluarga sebagai pondasi agama terlebih dahulu, khususnya orang tua sebagai madrasah/ pendidikan utama dalam kehidupan berumah tangga".

Kewajiban seorang suami dalam melindungi, mendidik istri dan anakanaknya dalam kehidupan berumah tangga. Ketika suami ingin melakukan dakwah para anggota Jamaah Tabligh tidak jarang menerima perkataan yang seakan-akan mereka menelantarkan anak dan istrinya ketika meninggalkan mereka berdakwah. Khususnya dalam persoalan nafkah untuk mereka dan mengajarkan atau mendidik anaknya agar paham mengenai ilmu agama. Ketika Khuruj fii sabilillah Jamaah Tabligh tidak jarang menerima perkataan yang

${ }^{20}$ Syamsir Alam, Wawancara, di Kelurahan Masumpu Kecamatan Tanete Riattang Kabupaten Bone, 28 Juni 2019. 
seakan-akan mereka menelantarkan anak dan istrinya ketika meninggalkan untuk berdakwah. Hal yang dikatakan oleh bapak Muh. Ikbal, yaitu:

"Khusunya persoalan nafkah untuk mereka dan mengajarkan atau mendidik anaknya agar paham mengenai ilmu agama. Namun, pada hakikatnya ketika Khuruj fii sabilillah tersebut mereka bukan hanya berdakwah dengan cara Khuruj fii sabilillah melainkan juga belajar ilmu agama, yang diperolehnya ketika Khuruj dan ilmu tersebut akan ia terapkan dan amalkan dirumah kepada anak, istri dan anggota keluarga lainnya". ${ }^{21}$

Sehingga tidak tepat kalau seandainya dikatakan bahwa suami yang ikut berdakwah dengan Jamaah Tabligh tidak mengajarkan atau bahkan menyampingkan urusan mendidik anak, istri dan anggota keluarga lainnya. Karena pada dasarnya bahwa sebelum melakukan dakwah biasanya istri diberikan nasehat dari suaminya dari berbagai hal, seperti dalam urusan mengurus anak, menjaga harta, serta selalu giat melaksanakan ibadah sesuai yang diperintahkan oleh Allah Swt. Hal serupa disampaikan oleh Bapak Muh. Ashar, yaitu:

"Pada hakikatnya bahwa ketika melakukan dakwah bukan hanya saja dakwah yang semata-mata dilakukan melainkan juga belajar ilmu agama yang diperolehnya ketika berdakwah dan namun ilmu yang didapat tersebut akan diterapkan dan diamalkan pula di dalam rumah kepada istri dan anak-anaknya dan anggota keluarga lainnya". ${ }^{22}$

Ketika seseorang yang melakukan dakwah atau Khuruj fii sabilillah mereka mendapatkan banyak ilmu agama sehingga tidak perlu khawatir ketika mereka pulang di rumah disebabkan karena mereka sudah ada bekal yang dibawa dari dakwah tersebut, hanya saja mereka amalkan di dalam rumah serta kepada anggota keluarga lainnya. Namun tujuan dari dakwahnya ini yaitu untuk memperbaiki diri sendiri di dalam kehidupan rumah tangga. Hal ini disampaikan oleh Bapak A. Fadli, beliau mengatakan:

"Sebagai tujuan utama dari dakwah Jamaah Tabligh itu adalah untuk diri sendiri, dan mengingatkan orang lain agar selalu berbuat kebaikan seperti melaksanakan shalat di masjid, dan mengamalkan apa-apa yang telah didapatkan ketika keluar melakukan Khuruj di dalam kehidupan berumah tanggga agar senantiasa menjadikan rumah sebagai keluarga

\footnotetext{
${ }^{21}$ Muh. Ikbal, Wawancara di Kelurahan Manurungnge Kecamatan Tanete Riattang Kabupaten Bone, 20 Juni 2019.

${ }^{22}$ Muh. Ashar, Wawancara di Kecamatan Tanete Riattang Kab. Bone, 18 Juni 2019.
} 
yang sejahtera dan damai, serta mempertebal keimanan kita kepada Allah Swt.". ${ }^{3}$

Sama halnya yang diungkapkan oleh Bapak Muh.Ashar :

"Tujuan dari dakwah Jamaah Tabligh itu adalah untuk memperbaiki diri sendiri, keluarga dan menimba ilmu serta untuk mempertebal keyakinan kepada Allah Swt., dan mengamalkan apa yang telah didapat ketika melakukan dakwah di dalam kehidupan berumah tangga".

Kewajiban suami seperti mendidik anak pada dasarnya adalah kewajiban bersama antara suami istri. Namun dalam keluarga Jamaah Tabligh lebih menyerahkan kewajiban tersebut terhadap istri, ketika suaminya keluar untuk berdakwah dijalan Allah Swt. Namun pada dasarnya bahwa ketika suami keluar dari dakwahnya dia sibuk untuk mempersiapkan nafkah untuk istri dan anakanaknya dengan berbagai cara seperti, bekerja, berdagang, dan lain sebagainya untuk persiapan melakukan dakwah berikutnya sesuai yang dikatakan oleh Bapak Syamsir Alam:

"Di dalam kehidupan berumah tangga memang sebetulnya dalam hal mendidik, membimbing itu merupakan hak bersama dalam mengurus, tetapi ketika keluar berdakwah dijalan Allah Swt. semuanya itu saya serahkan kepada istriku. Karena sebelum keluar, diadakan dulu nasihat, bimbingan agar supaya di dalam kehidupan rumah tangga menjadi harmonis dan tidak ada lagi keragu-raguan dalam semua hal". ${ }^{4}$

Hal sama yang diungkapkan oleh bapak Muh. Ashar:

"Langkah yang harus ditempuh oleh seorang suami dalam hal mendidik anak dan istrinya ketika mereka ingin keluar, maka suami akan senantiasa selalu memberikan bimbingan ilmu agama kepada anggota keluarga agar supaya istri dan anak merasa bahagia". ${ }^{25}$

Jadi dapat disimpulkan bahwa mengenai pemenuhan hak dan kewajiban suami istri dalam lingkup Jamaah Tabligh di dalam kehidupan berumah tangga itu tidak lepas yang namanya nafkah. Sehingga dapat dikatakan bahwa hak dan kewajiban seorang suami di dalam kehidupan berumah tangga itu merupakan suatu kewajiban yang harus dipenuhi agar dapat mewujudkan kehidupan keluarga

\footnotetext{
${ }^{23}$ A.Fadli, Wawancara di Mesjid Al-Fatihah Kelurahan Manurungnge Kecamatan Tanete Riattang Kabupaten Bone, 14 Juni 2019.

${ }^{24}$ Syamsir Alam, Wawancara, di Kelurahan Masumpu Kecamatan Tanete Riattang Kabupaten Bone, 28 Juni 2019.

${ }^{25}$ Muh. Ashar, Wawancara di Kecamatan Tanete Riattang Kab. Bone, 18 Juni 2019.
} 
yang bahagia, damai, sejahtera. Karena pada dasarnya bahwa di dalam suatu keluarga setelah adanya ikatan perkawinan antar suami dan istri maka hendaklah terdapat hak dan kewajiban masing-masing. Agar suami dan istri mengetahui hak dan kewajibannya masing-masing, maka hendaklah keretakan tidak terjadi di dalam kehidupan berumah tangga. Namun jika tidak mengetahui hak dan kewajibannya maka akan selalu muncul rasa yang tidak harmonis di dalam kehidupan berumah tangga sesuai yang diinginkan.

Sebelum seorang suami ingin keluar untuk berdakwah maka terlebih dahulu mereka meminta izin kepada istri dan anaknya, selama mereka diberikan izin untuk berdakwah maka diadakan pula musyawarah keluarga bersama antara suami dan istri mengenai bekal atau uang yang akan dibutuhkan selama suami keluar beberapa hari atau beberapa bulan.

Jadi dapat ditegaskan bahwa seorang suami ketika ingin keluar untuk berdakwah maka segala kebutuhan yang dibutuhkan oleh istri dan anak dipenuhi. Namun pada hakikatnya bahwa mengenai dalam masalah nafkah, tempat tinggal, dan kebutuhan lainnya sudah terpenuhi. langkah awal yang harus dilakukan itu dengan mengadakan musyawarah keluarga bersama. Karena tanpa adanya musyawarah maka semuanya tidak akan berjalan dengan baik dan tidak akan selalu hidup bahagia, oleh karena itu musyawarah adalah kunci utama untuk berdakwah dijalan Allah Swt., dan musyawarah sangat penting dilakukan apabila kita hendak melakukan sebuah usaha dakwah.

Berdasarkan data dan fakta di lapangan bahwa tidak sedikit pula rumah tangga keluarga yang harus berpisah dengan kepala keluarga (suami istri), akibat ketidaksiapan istri menerima suami yang harus selalu keluar meninggalkan keluarganya, berikut petikan wawancara istri Jamaah Tabligh di Melle:

"Yang pada awalnya Istri merasa senang dalam kehidupan keluarga, karena terjadi perubahan dalam diri suami yang jarang beribadah berangsur taat beribadah, namun seiring waktu berubah kepentingan akan duniawi tidak lagi diperhatikan mencari nafkah diabaikan bahkan berselisih hingga akhirnya berakhir dengan perceraian". ${ }^{26}$

\footnotetext{
${ }^{26}$ Istri di Melle Jamaah Tabligh, Wawancara di kediamannya Kab. Bone, 19 Juni 2019
} 
Hal yang sama pula dialami oleh Rahmawati mantan istri Jamaah Tabligh, dalam petikan wawancara" ia mengatakan:

“Tidak siap menerima perilaku suami yang harus selalu begadang malam hari keluar rumah dengan alasan dakwah, sehingga pada waktu pagi yang seharusnya melakukan aktivitas tidak lagi dilakukan karena mengantuk dan harus tidur, akhirnya mereka berakhir dengan cekcok dan bercerai.

Hal yang beda lagi dirasakan $\mathrm{Hj}$ Uni, beliau mengatakan tentang "berpisah tempat tinggal" seperti dalam petikan wawancaranya:

"Untuk apa hidup bersama dengan keluarga yang urusan keluarga beban ekonomi berada pada istri. Meskipun istri sebagai pekerja bukan berarti ekonomi harus dibebankan kepada istri apapun alasannya sekalipun dengan kata Khuruj fi sabilillah. Keluar berdakwah di jalan Allah Swt..

Lain halnya dengan Bapak Ahdar ${ }^{27}$ (Jamaah Tabligh)' yang semula istri tidak menerima perlakuan suami yang setiap waktu keluar, namun dengan memberi pengertian tidak juga diterima maka diajaknya istrinya ikut serta menyaksikan apa yang dipraktekkan di luar sana dengan berdakwah perlahanlahan dimengerti dan menerima, dengan tidak mengabaikan pemenuhan kebutuhan keluarga baik sandang pangan dan papan.

Berdasarkan hasil wawancara para Jamaah Tabligh pada intinya dapat diklasifikasikan bahwa terdapat tiga bentuk sikap keluarga Jamaah Tabligh, diantaranya yang pertama, keluarga atau istri tidak terima, jika harus ditinggal oleh suaminya dengan kegiatan Khuruj, sedangkan yang Kedua Keluarga (istri) menerima tidak sepenuhnya, dan yang Ketiga, menerima sepenuhnya.

Keluarga pertama tidak terima artinya benar-benar tidak rela jika harus ditinggal Khuruj oleh kepala keluarganya ataupun suaminya yang pada kenyataannya keluarga ini berakhir dengan perceraian, sedangkan keluarga yang menerima tidak sepenuhnya, ketika ditinggal timbul lagi riak perselisihan dalam keluarganya, begitupun saat kembali kepala keluarganya ke rumah, mereka menerima namun terpaksa hidup dalam ambigu dua pilihan bertahan dengan selalu menimbulkan percekcokan dalam keluarga, sementara keluarga menerima

${ }^{27}$ Bapak Ahdar Anggota Jamaah Tabligh, Wawancara di Mesjid Al Abrar Kabupaten Bone, tanggal 7 Agustus 2019 
sepenuhnya ini, semata-mata urusan dunia bukan lagi hal penting akan tetapi kehidupan dunia adalah persinggahan sementara, semuanya lillahitaala,.

Oleh karena itu bagi Jamaah Tabligh yang menerima sepenuhya berpandangan bahwa wajib memberikan semangat terhadap usaha dakwah yang dilakukan oleh suaminya, bahkan istri ikut mendapatkan pahala jika mendukung suaminya jihad fisabilillah dan istri diberikan bekal oleh suaminya yaitu pondasi mengenai keutamaan berdakwah dan hak istri dalam mendorong suaminya untuk melakukan Khuruj fisabilillah.

Selain itu suami wajib memberikan nafkah selama melakukan Khuruj sesuai dengan kebutuhan istri. Kewajiban seorang suami yang menjadi hak istri seperti nafkah, yang seharusnya hal tersebut dapat dipenuhi oleh seorang suami dengan bekerja, usaha maupun berdagang setiap hari dan diberikan dengan ukuran nafkah sesuai kebutuhan harian istri. Ketika suami melakukan Khuruj fisabilillah pemenuhan nafkah yang diberikan oleh seorang suami kepada istrinya tersebut tetap dilakukan oleh suami dan nafkah tersebut diberikan sesuai dengan besaran nafkah yang biasa diberikan suami kepada istrinya sesuai dengan kebutuhan yang dibutuhkan keluarga dalam setiap harinya dan nafkah tersebut diberikan dengan cara menjumlahkannya sesuai dengan berapa lama suaminya melakukan Khuruj fisabilillah. Hal ini sesuai dengan al-Quran surat Ath-Thalaq (65) ayat 7:

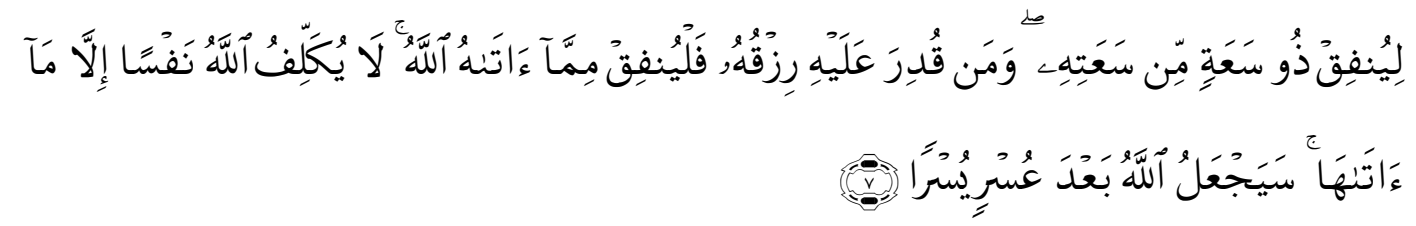

Terjemahnya: "Hendaklah orang yang mempunyai keluasan memberi nafkah menurut kemampuannya, dan orang yang terbatas rezekinya, hendaklah memberi nafkah dari hartanya yang diberikan Allah Swt. kepadanya. Allah Swt. tidak membebani seseorang melainkan (sesuai) dengan apa yang diberikan Allah Swt. kepadanya. Allah Swt. kelak akan memberikan kelapangan setelah kesempitan., 28

Selain itu istri wajib menjaga diri, mendidik anak, selama suami melakukan Khuruj fisabilillah. Berdasarkan al-Quran surat Al-Nisa' Ayat 34 kewajiban istri untuk taat kepada suaminya dan menjaga diri ketika suami tidak 446.

\footnotetext{
${ }^{28}$ Departemen Agama RI, Alquran dan Terjemahan, (Bandung: CV. Diponegoro 2006), h.
} 
ada. Mengenai pemenuhan hak dan kewajiban suami selama mereka ingin keluar melakukan dakwah suami akan memberikan nafkah berupa bekal berupa nafkah sesuai kebutuhan istri, dan nafkah yang diberikan suami kepada istrinya itu merupakan tabungan dari suaminya. Maka hendaknya sebagai seorang istri nafkah yang diberikan oleh suami maka hendaknya disyukuri.

Kewajiban adalah apa yang mesti dilakukan seseorang terhadap orang lain. Dalam hubungan rumah tangga suami mempunyai hak dan begitu pula istri mempunyai hak maka dari hal tersebut keduanya mempunyai beberapa kewajiban. Dengan diaturnya hak dan kewajiban suami istri maka dambaan suami istri dalam bahtera rumah tanggannya akan dapat terwujud, karena didasari rasa cinta dan kasih sayang. ${ }^{29}$

Sebagai seorang suami dalam hal mengenai nafkah untuk diberikan kepada istrinya sesuai dengan prosedur yang menjadi syarat untuk berdakwah maka tidak terdapat kesalahan terhadap hak dan kewajibannya kepada istri dan anggota keluarga lainnya, selama istri ridha terhadap nafkah yang diberikan, dan selalu mensyukuri pemberian nafkah dari seorang suami untuk memenuhi kebutuhan rumah tangganya. Jadi boleh saja seorang suami keluar untuk berdakwah, selama tidak melanggar syariat Islam, karena pada dasarnya bahwa kehidupan dalam berumah tangga itu merupakan sumber utama agar dapat menumbuhkan rumah tangga yang sakinah, mawaddah, dan warahmah. Namun dalam masalah dakwah itu sebagai soal kedua apabila tidak dilakukan, asalkan selama mereka memenuhi hak dan kewajibannya di dalam kehidupan berumah tangga. Karena pada dasarnya bahwa tidak terdapat perbedaan dengan masyarakat biasa dengan anggota Jamaah Tabligh, hanya saja di kalangan Jamaah Tabligh, mengenai hak dan kewajibannya sebagai suami, terlebih dahulu mereka harus memenuhi hak dan kewajibannya dengan mengadakan pula musyawarah bersama antara suami dan istri untuk mewujudkan keluarga harmonis.

${ }^{29}$ Ahmad Rofiq, Hukum Perdata Islam di Indonesia (Cet. I; Jakarta: PT.Raja Grafika, 2013) h. 147. 


\section{E. PENUTUP}

Mengacu pada pembahasan di atas, maka dapat disimpulkan bahwa pemenuhan hak dan kewajiban suami istri di dalam kehidupan berumah tangga mengenai sikap Jamaah Tabligh itu tidak lepas dari sikap saling menyayangi, saling pengertian, saling menghormati, saling melaksanakan hak dan kewajiban di dalam rumah tangga oleh Jamaah Tabligh di Kabupten Bone. Bahwa hak dan kewajiban seorang suami di dalam kehidupan berumah tangga itu merupakan suatu kewajiban yang harus dipenuhi agar dapat mewujudkan kehidupan keluarga yang bahagia, damai, sejahtera. Sehingga Sebelum seorang suami ingin keluar untuk berdakwah maka terlebih dahulu mereka meminta izin kepada istri dan anaknya, selama mereka diberikan izin untuk berdakwah maka diadakan pula musyawarah keluarga bersama antara suami dan istri mengenai nafkah bekal atau uang yang akan dibutuhkan selama suami keluar beberapa hari atau beberapa bulan.

Namun pada hakikatnya bahwa mengenai dalam masalah nafkah, tempat tinggal, dan kebutuhan lainnya sudah terpenuhi di kalangan Jamaah Tabligh, langkah awal yang harus dilakukan itu dengan mengadakan musyawarah keluarga bersama. Sekalipun ditemukan di lapangan beberapa keluarga yang tidak siap untuk ditinggal Khuruj oleh kepala keluarganya, namun inilah dinamika kehidupan keluarga yang harus dilakoni oleh karena itu, tanpa adanya musyawarah maka semuanya tidak akan berjalan dengan baik dan tidak akan selalu hidup bahagia.

Terdapat keluarga yang tidak terima dan tidak rela jika harus ditinggal Khuruj oleh kepala keluarganya ataupun suaminya yang pada kenyataannya keluarga ini berakhir dengan perceraian, sedangkan keluarga yang menerima tidak sepenuhnya, ketika ditinggal timbul lagi riak perselisihan dalam keluarganya, begitupun saat kembali kepala keluarganya ke rumah menerima namun terpaksa hidup dalam ambigu dua pilihan, bertahan dengan selalu menimbulkan percekcokan dalam keluarga, sementara keluarga menerima sepenuhnya ini, semata-mata urusan dunia, bukan lagi hal penting akan tetapi kehidupan dunia adalah persinggahan sementara, semuanya lillahitaala. 


\section{DAFTAR PUSTAKA}

AF, Hasanuddin. Perkawinan dalam Perspektif Al-Qur;an, Jakarta: Nusantara Damai Pers,.2011

Ahmad, Haidlor Ali. Respon Pemerintah Ormas dan Masyarakat Terhadap Aliran Keagamaan di Indonesia, Jakarta:.2007

Beni Ahmad Saebani, Fighi Munakahat 1. Cet. I; Bandung: Pustaka Setia. 2001.

Departemen Agama RI. Al-Qur'an dan Terjemah. Semarang: CV Alwaah, Sinar Grafika Offset, 1989.

Hasan, M. Ali. Pedoman Hidup Berumah Tangga dalam Islam, Cet. I, Jakarta: Prenada Media, 2003.

Ilamuddin, Haryu. PsikologiPendidikan. Cet. I; Yogyakarta: Pustaka Pelajar, 2012

Mardani, Hukum Perkawinan Islam, Yogyakarta: Graha Ilmu, 2011.

Nadwi, Ali. Riwayat Hidup dan Usaha Dakwah Maulana M. Ilyas, Yogyakarta: As-Shaffi, 1999.

Nata, Abuddin,. Metodologi Studi Islam, Cet. IV; Yogyakarta: Gajah Mada University Press, 2012.

Nabawi, Az-Zuhaili, Wahbah. Fiqh Islam wa adillatuhu Terj. Abdul Hayyie alkattani, Jakarta: Gema Insani,.2011.

An-Nadr, M. Ishaq, Khuruj Fisabillah : Sarana Tarbiya Ummah Untuk Membentuk SIfat Imaniyah, Bandung : Al Islah Press, 2012.

Rofiq, Ahmad, Hukum Perdata Islam di Indonesia. Cet. I; Jakarta: PT.Raja Grafika,.2013.

Rasmianto, Paradigma Pendidikan dan Dakwah Jamaah Tablig, Malang :UIN Maliki Press, 2011.

As-Subki,. Fiqh Keluarga (Pedoman berkeluarga dalam Islam), Cet. I; Jakarta: 2010.

As-Sribuny, Abdurrahman Ahmad, Kupas Tuntas Jamaah Tabligh, Cerebon: Pustaka, 2012.

Syarifuddin, Amir, Hukum Perkawinan Islam Di Indonesia. Cet I; Jakarta: Pranada Media, 2006.

Sugiyono, Metode Penelitian Kualitatif, Kuantitatif dan $R \& D$, Bandung: Alfabeta, 2014. 